Original paper

\title{
Understanding Households' Perceptions Regarding the Effect of a Natech Accident on Residential Property Values: The Case of Ichihara City
}

\author{
Waqas Ahmed $\operatorname{Raza}^{1}$ and Ana Maria Cruz ${ }^{2 *}$
}

Received: 15/10/2020 / Accepted: 16/11/2021 / Published online: 14/12/2021

\begin{abstract}
This research investigated households' perceptions concerning the effects of a natural hazard-triggered chemical accident (known as a Natech) on residential property values in Ichihara city, Japan, where a Natech accident occurred in 2011 following the Great East Japan earthquake and tsunami. Furthermore, the household survey investigated households' perceptions regarding the effect that the disclosure of risk information concerning potential chemical and Natech accidents on future property values. Data was collected through a stratified random survey of households within three kilometers of the Chiba industrial park in Ichihara City, Japan, where the Natech accident occurred. The household survey findings indicate that the respondents felt that the land price did not decline due to the Natech accident in 2011. However, they consider chemical and Natech accidents a threat to their lives and property. They are concerned that chemical accidents alone or triggered by natural hazards may happen again at the Chiba industrial park and about the potential for the accidents to decline property values in the future. The results also showed that respondents want the government to disclose chemical risk information, but they are also concerned that the disclosure will affect future property values. The study results have implications on Natech risk governance at the community and industry level. The survey results highlighted the need to develop risk communication strategies taking into consideration households concerns, and finding ways to counterbalance the negative effects that the disclosure of risk information may have.
\end{abstract}

Keywords: Natech, Chemical accident, Property values, Risk information disclosure, Great East Japan earthquake

\footnotetext{
${ }^{1}$ Department of Urban Management, Graduate School of Engineering, Kyoto University

${ }^{2}$ Disaster Prevention Research Institute, Kyoto University

* Corresponding author email: cruznaranjo.anamaria.2u@kyoto-u.ac.jp
} 


\section{INTRODUCTION}

The worldwide frequency and severity of natural adversities have demonstrated an expansion in recent decades. Natural disasters such as floods, tsunamis, and earthquakes have had an undeniably effect on lives and properties (Gentle et al. 2001). In recent years, earthquakes, floods, and tsunamis have additionally caused chemical accidents. These natural hazard triggered chemical accidents are called "Natechs" (Krausmann et al. 2017). For example, after the severe Tohoku earthquake in Japan in 2011, several chemical industrial parks along the northeast Pacific Ocean coast in Japan were severely damaged. In Ichihara city, Chiba Prefecture, 17 liquefied petroleum gas (LPG) storage tanks at the Cosmo Oil Refinery were burnt entirely, resulting in fireballs with an estimated diameter of 600 meters, causing six injuries and damage to nearby vehicles, broken windows, and damaged shutters and roof shingles in nearby residential areas (Koseki et al. 2012; Krausmann and Cruz 2013). The earthquake and tsunami also caused Japan's worst nuclear disaster at the Fukushima Daiichi nuclear power plant. The residents of Fukushima prefecture and nearby areas responded with anxiety about the possibility of radiation exposure. The government's risk communication system did not work well since the information was not systematically or consistently provided, and government sources transmitted different information without considering consistency (Kinoshita 2014). Consequently, people did not know who or what to believe.

There is currently no regulation in Japan that explicitly requires industry to disclose hazard and risk information regarding the potential for chemical and Natech accidents to nearby residents. Several interviews with government officials and local residents concerning the disclosure of this type of information to the public revealed the perception that the information could lead to a decline in property values. Up to date, there is little research in Japan that could help support or deny these assumptions. In this study we are interested in understanding the effect of the Natech accident at Ichihara city during the Great East Japan earthquake on household's perception regarding residential property values following the chemical accident triggered by the Great East Japan earthquake. Furthermore, we explore households' perceptions concerning the effect on property values of disclosure of information regarding future chemical and Natech accidents.

\section{THE RIGHT TO KNOW}

Risk communication gains explicit significance in disaster risk management regarding the extensive scale of complex disasters, specifically technological disasters caused by natural hazards. The disclosure of chemical risk is seen as a citizen's right in many developed countries (see, for example, the Emergency Planning and Community Right-to-Know Act (EPCRA) in the United States; and the Seveso III Directive in the European Union), and in fact, it is 
considered unethical not to inform residents about risks they are being subjected to involuntarily (EPCRA 2012; European Union 2012). Nevertheless, due to several "landmark" accidents, awareness of Natech risk and the need for Natech risk reduction has increased over the past decades. For example, the European Union began taking concrete action following a cyanide spill in the Baia Mare mining disaster in Romania in 2000 and releasing chlorine and other hazardous substances from a flooded chemical facility in the Czech Republic in 2002. On the other hand, the 2011 Fukushima nuclear accident was a wake-up call that put Natech risks on the global agenda.

Although Natech risk awareness has increased during the last few decades, there are currently no regulations requiring Natech risk information disclosure in Japan. According to Ikeda (2013), Japan seems to be slightly lagging behind the European Union and the United States to encourage chemical risk communication. In Japan, little to no information about the chemical risk is provided to people living near industrial parks or in hazard-prone areas due to the fear that disclosure will make residents panic and adversely influence property values. Figueroa (2013) reported that the Japanese position on disaster risk information disclosure had been put under question from the 'bottom-up' through a surge in citizen activism after the Tohoku Earthquake in 2011 and the consequent nuclear accident. After the nuclear power plant accident and other chemical accidents caused by the Great East Japan earthquake and tsunami in 2011, there is an increasing concern about Natech accidents in Japan. The Great East Japan Earthquake demonstrated that generally, well-prepared countries are also at risk of suffering Natech accidents (Koseki et al. 2012; Krausmann and Cruz 2013). Risk communication is considered a critical element for managing Natech risk effectively. An ultimate reason for disclosure of risk information is a duty of care, and also, it is the fundamental right of citizens. Although local government authorities in different countries may acknowledge a responsibility to notify residents about their level of exposure to hazards, good intentions may not be appreciated due to the fear that disclosure will antagonistically affect residential property values (Yeo 2004). Therefore, this research aims to understand the effect of the Natech accident at Ichihara city on households' perception regarding property values following the disaster, and their perception regarding the disclosure of information about potential chemical and Natech accidents on future property values. The ultimate goal of this research is to better understand if residential property value is in fact an important concern for resdients when discussing chemical and Natech risk information disclosure. The findings of the study could help government authorities in developing communication strategies that are sensitive to this issue, seeking to counter balance any perceived and real effects.

\section{PERCEIVED AND REAL CHANGES IN PROPERTY VALUES DUE TO HAZARDS}


According to several studies, the decline in property value mostly depends on the residents' perception of the hazardous event and its severity. Zhang et al. (2010) indicated that if environmental hazards are perceived as dis-amenities, property values in the proximity of hazard sources would be expected to be lower than those in the less vulnerable areas. Furthermore, if an actual accident/disaster affects or damages an area on a larger scale, there is a high probability that the accident could decrease the property values.

There are however limited studies that have considered residents' perceptions and concerns regarding the effects of disasters on property values, and much less have focused on chemical and Natech hazards and risk.

A few studies have investigated the impact that proximity of hazardous industrial facilities has on property values (Boxall et al. 2005, Grislain-Letrémy and Katossky 2014, and Zhang et al. 2010). Some studies suggest that natural and technological hazards have a negative effect on property values, while others indicate no effect. One study investigated the effect of the Fukushima nuclear power plant accident on property values. According to Tanaka and Managi (2016), the Fukushima accident caused widespread pollution of the land by radioactive contamination and decreased the property values in Fukushima prefecture and nearby areas.

On the other hand, several studies have investigated the impact of natural hazards on property markets (Beron et al. 1997; Eves and Wilkinson 2014; Lamond 2008; Montz 1993; Rajapaksa et al. 2016; Rambaldi et al. 2013; Samarasinghe and Sharp 2010; Troy and Romm 2004; S Yeo, 2004; Stephen Yeo 2003; Zhai et al. 2003). Some of the researchers found a negative effect, whereas others found no impact on property values. In light of seven investigations of variations in property values before and after flood risk declarations in Australia, Canada, New Zealand, and the United States, Stephen Yeo (2003) found no price effect in two cases, a modest decline in property prices in three cases and a slight increment in property prices in the remaining two.

Despite the substantial literature on environmental hazards' effect on residential property value, the findings are not consistent. There may be many reasons for this inconsistency, such as Naoi et al. (2009) indicated that individuals give little contemplation to various hazards and other negative environmental factors in their need framework because they tend to underestimate risk. For example, Zhai et al. (2003) found that people generally prefer more affordable property instead of a low risk of flooding (in a case study of the 2000 Tokai flood in Japan). Moreover, Beron et al. (1997) reported that if a hazard-prone area is attractive with many amenities, there will be little effect on property values. Furthermore, proximity to the workplace may be more important, than considerations concerning the hazards. In a study regarding industrial facilities, the researchers found that staff may want to live near their workplace (industrial site) to diminish travel times (Kivimäki and Kalimo 1993), so they prefer to live near the hazardous area despite knowing about hazards and potential risks. 
A finding from the literature is that a real hazardous event is bound to severely influence property values more than the hazard-prone area designation. In many cases, property values have changed after an event happened, not before the event, even if the risk information has been disclosed. However, in places where demand for housing is strong, even an actual destructive event may have little or no impact on property value. For instance, flooding of Sydney's Georges River Valley in 1986 decreased property values for a few months only. According to Lambley and Cordery (1997), high population growth and subsequent housing deficiency brought about a buoyant market, strikingly flexible to external impact, which tended to obscure any permanent effect upon the market. Evidence from different investigations suggests mixed results regarding the decrease in property market value due to the event occurrence and, or risk information disclosure. As mentioned above, according to the studies, property values decrease if people perceive environmental hazards as dis-amenities. The above studies concerned actual natural disaster occurrence, or the disclosure of natural hazard and/ or risk information. However, few studies have looked into the effect of Natech and chemical accidents on property values. In addition, previous studies have not focused on households' perceptions and their concerns while investigating the effect of disasters on property values. In this study, we are interested in understanding the effect of the Natech accident on households' perception regarding property values, households' concerns and worries regarding the presence and proximity of the hazards (the industrial installation near the coast) to their properties, their views regarding the need for disclosure of information about potential chemical and Natech accidents risks, and their perception concerning the disclosure of such information on future property values.

\section{METHODOLOGY}

Data for this study was collected through a stratified household survey applied in Ichihara City, Chiba Prefecture, Japan. Ichihara city was selected because of the Natech accident that occurred there in 2011 following the Great East Japan earthquake. The sections below will present the details of the Natech accident and the survey design.

\subsection{Cosmo oil refinery fires in Ichihara City, Japan}

To conduct the household survey, a case study area was selected near the Chiba industrial park in Ichihara city, where the Natech accident, involving explosions at the Cosmo Oil Refinery, was triggered by the Great East Japan Earthquake in March 2011. The earthquake triggered a fire and several explosions at the Cosmo Oil Refinery's liquified petroleum gas (LPG) tank farm. All the 17 LPG storage tanks were completely burnt or severely damaged (Koseki et al., 2012). The shockwaves from the explosion broke windows and damaged 
shutters and roof shingles in nearby residential areas (Koseki et al., 2012; Krausmann and Cruz 2013).

\subsection{Design of the Household Survey}

To examine the households' perceptions regarding the effect of the Natech accident and risk information disclosure on property values, a questionnaire was designed and translated into the Japanese language. The questionnaire included questions in both English and Japanese. The questionnaire had different sections, including a section on socio-demographic characteristics, households' perceptions regarding Natech accidents' effect on property values, and their perceptions about chemical and Natech accident risks. Furthermore, questions regarding the length of time living at the location, and whether they experienced the Natech accident in 2011 were also included. The questionnaire also had subsections focusing on households' concerns and perceptions about industrial park proximity, their demand for risk information and their perceptions about information disclosure effects on future property values.

A list of registered addresses of households (128,316 registered households in 2020) in Ichihara city was collected from the Ichihara post office. The list provided by the Ichihara Post office had more than 100 towns that belong to Ichihara city. From that list provided by the Ichihara post office, six towns within $3 \mathrm{~km}$ of the industrial park were selected. The selected towns were Goi, Shiroganecho, Iwasaki, Kimizuka, Gosho, and Tamasaki. After selecting the towns for the survey, we visited the Ichihara city post office and provided them with the list of selected towns and the number of questionnaires to be mailed out in each town. We requested them to send questionnaires to the households living near the industrial park in each town within three kilometers from the Chiba industrial park in Ichihara city. Households within the $3 \mathrm{~km}$ perimeter for each town were selected randomly. A total of 1400 questionnaires were mailed out to the residents living in the six different towns in Ichihara city near the Chiba industrial park. A return envelope was also enclosed in each questionnaire envelope. Respondents were given one and a half months to fill out the questionnaire and send it back.

\section{ANALYSIS AND RESULTS}

Out of 1400 questionnaires that were mailed to the households, we received 210 responses. So, the overall response rate of the town mail survey was $15 \%$. The response rate is low because the questionnaire survey was voluntary, and no compensation was paid to the survey participants. Another reason may be the type of mailing system used, called "town mail", where the envelopes are not addressed to any person in the household. This system is often used in Japan, which substantially lowers the costs of the mail survey, but results in a low response rate. A similar response rate of $14.3 \%$ was reported in the literature in Japan by Kotani and Yokomatsu (2019). 


\subsection{Socio-Demographic Characteristics}

Table 1 shows the socio-demographic characteristics of the respondents. Almost $80 \%$ of the household respondants were male, and all were Japanese. Most of the respondents, 69.1\%, were 60-years-old or older. According to the Statistics Bureau of Japan (2015), the total population of Ichihara city is 274,656 , out of which 125,203 (45.6\%) people are older than 50years old. Thus, our sample was older. About $52.4 \%$ of the respondents have only high school education, whereas $37.1 \%$ of respondents have a bachelor's degree; out of that, $6.3 \%$ also have a master's degree. The majority of the respondents had a household size of either 2 or 3 persons, and the average household size was 2.58 persons. $36.7 \%$ of the households have children living with them. Most of the respondents (96.7\%) were homeowners, and most of them $(84.8 \%)$ were living in wooden houses. Only $3.8 \%$ of the respondents lived in reinforced concrete structures, whereas $4.3 \%$ were living in steel frame reinforced concrete structures. Almost all the participants $(99.5 \%)$ lived in their current house in Ichihara city near the industrial park for many years, and the mean duration of living was 27.4 years. Some of the respondents $(18.1 \%)$ also owned vacant plots. Almost $25 \%$ of the participants marked the average land price of $60,000 \mathrm{yen} / \mathrm{m}^{2}$, whereas $40.2 \%$ of the respondents marked the average land price in yen $/ \mathrm{m}^{2}$, ranging from 60,000 to 80,000 . From the survey participants, $16.2 \%$ were living within $1-\mathrm{km}$ from the Chiba industrial park, $48.5 \%$ were living within $1-2 \mathrm{~km}$, whereas the remaining $32.3 \%$ (excluding 2.9\% who did not respond to this question) were living within $2-3 \mathrm{~km}$ from the Chiba industrial park. $11.9 \%$ of the respondents were working at the Chiba industrial park at the time of the survey.

\subsection{Households' Perceptions Regarding the Effect of a Natech Accident on Property Values}

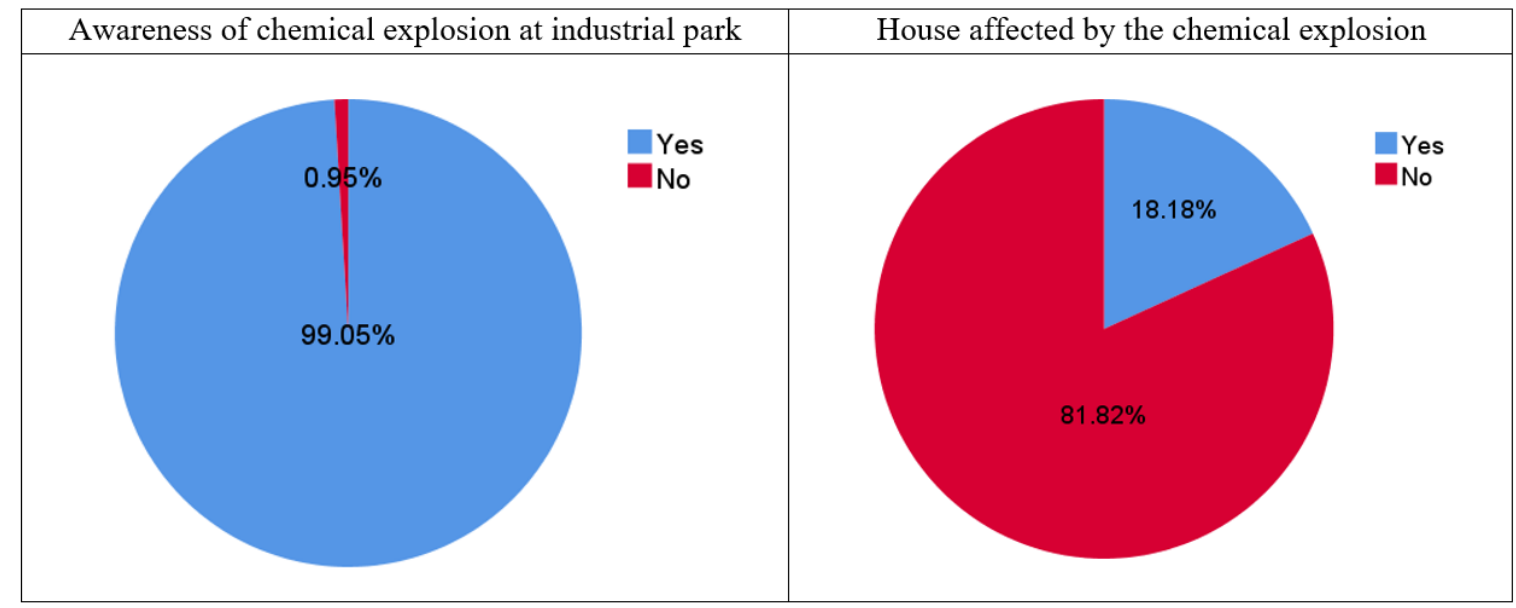

Figure 1. Survey participants' awareness of chemical accidents and participants houses affected by the chemical accidents 
Table 1. Socio-demographic characteristics of the survey participants

\begin{tabular}{|c|c|c|c|}
\hline \multicolumn{2}{|c|}{ Socio-demographics characteristics of survey participants } & \multirow{2}{*}{$\begin{array}{c}\text { Frequency } \\
43\end{array}$} & \multirow{2}{*}{$\begin{array}{c}\text { Percentage \% } \\
20.5 \%\end{array}$} \\
\hline & Female & & \\
\hline Gender & Male & 167 & $79.5 \%$ \\
\hline \multirow{5}{*}{ Age } & $30-39$ & 8 & $3.8 \%$ \\
\hline & $40-49$ & 15 & $7.1 \%$ \\
\hline & $50-59$ & 42 & $20.0 \%$ \\
\hline & $60-74$ & 94 & $44.8 \%$ \\
\hline & $>=75$ & 51 & $24.3 \%$ \\
\hline \multirow{5}{*}{ Level of education } & High School & 109 & $51.9 \%$ \\
\hline & Technical School & 22 & $10.5 \%$ \\
\hline & Bachelor's degree & 64 & $30.5 \%$ \\
\hline & Master's degree & 13 & $6.2 \%$ \\
\hline & No response & 2 & $1.0 \%$ \\
\hline \multirow{6}{*}{ Size of Household } & 1 person & 20 & $9.5 \%$ \\
\hline & 2 persons & 105 & $50.0 \%$ \\
\hline & 3 persons & 49 & $23.3 \%$ \\
\hline & 4 persons & 22 & $10.5 \%$ \\
\hline & 5 persons & 8 & $3.8 \%$ \\
\hline & 6 persons & 6 & $2.9 \%$ \\
\hline \multirow[b]{2}{*}{ Children living in the house } & Yes & 77 & $36.7 \%$ \\
\hline & No & 133 & $63.3 \%$ \\
\hline \multirow[b]{2}{*}{ House ownership } & Owned & 203 & $96.7 \%$ \\
\hline & Rented & 7 & $3.3 \%$ \\
\hline \multirow{4}{*}{ Structure of house } & Reinforced concrete & 8 & $3.8 \%$ \\
\hline & Steel frame reinforced concrete & 9 & $4.3 \%$ \\
\hline & Light steel structure & 15 & $7.1 \%$ \\
\hline & Wooden & 178 & $84.8 \%$ \\
\hline \multirow[b]{2}{*}{ Ownership of vacant plot } & Yes & 38 & $18.1 \%$ \\
\hline & No & 172 & $81.9 \%$ \\
\hline \multirow{7}{*}{$\begin{array}{l}\text { Unit price per square meter of a } \\
\text { vacant plot }\end{array}$} & 60000 yen & 52 & $24.9 \%$ \\
\hline & $60000 \sim 70000$ yen & 42 & $20.1 \%$ \\
\hline & $70000 \sim 80000$ yen & 42 & $20.1 \%$ \\
\hline & $80000 \sim 90000$ yen & 13 & $6.2 \%$ \\
\hline & $90000 \sim 100000$ yen & 12 & $5.7 \%$ \\
\hline & More than 100000 yen & 20 & $9.6 \%$ \\
\hline & No response & 28 & $13.4 \%$ \\
\hline \multirow{7}{*}{$\begin{array}{l}\text { Distance from house to the } \\
\text { Chiba industrial park }\end{array}$} & Less than $500 \mathrm{~m}$ & 4 & $1.9 \%$ \\
\hline & $500 \sim 1000 \mathrm{~m}$ & 30 & $14.3 \%$ \\
\hline & $1000 \sim 1500 \mathrm{~m}$ & 41 & $19.5 \%$ \\
\hline & $1500 \sim 2000 \mathrm{~m}$ & 61 & $29.0 \%$ \\
\hline & $2000 \sim 2500 \mathrm{~m}$ & 36 & $17.1 \%$ \\
\hline & $2500 \sim 3000 \mathrm{~m}$ & 32 & $15.2 \%$ \\
\hline & No response & 6 & $2.9 \%$ \\
\hline \multirow{2}{*}{$\begin{array}{l}\text { Working at Chiba industrial } \\
\text { park }\end{array}$} & Yes & 25 & $11.9 \%$ \\
\hline & No & 185 & $88.1 \%$ \\
\hline
\end{tabular}


Since the blasts at the Chiba industrial park damaged window glasses, shutters, slate roofs, blew away heat insulators and other light-weighted materials, and stained or damaged vehicles (Krausmann and Cruz 2013) in the nearby residential areas, we asked the survey participants if they were aware of the chemical explosion (Natech accident) that occurred at the Cosmo Oil Refinery in the Chiba industrial park in March 2011 and if their houses were affected by the explosion. Almost $99.5 \%$ of the respondents were aware of the chemical accidents induced by the earthquake in 2011 at Cosmo Oil Refinery, as shown in Fig. 1.

The rest of the respondents who were not aware of the explosion were those who moved to Ichihara city after the explosion. Their duration of living in Ichihara city was less than nine years at the time of this survey. Only $18.2 \%$ of the participants responded that their houses were directly or indirectly affected (damaged) by the chemical accidents in 2011 . Whereas the majority of the participants $(81.8 \%)$ responded that the accidents did not damage or affect their houses or property.

It is pertinent to mention here that both the affected and non-affected participants lived within 3-km from the Chiba industrial park. From the (total affected $=18.2 \%$ ) affected participants, $18.4 \%$ resided within $1-\mathrm{km}$, whereas $52.6 \%$ lived within $1-2 \mathrm{~km}$ from the Chiba industrial park. From the (total non-affected $=81.8 \%$ ) non-affected participants, $16.3 \%$ lived within $1-\mathrm{km}$, whereas $49.7 \%$ lived within $1-2 \mathrm{~km}$ from the Chiba industrial park. The rest from both groups were residing within 2-3 km from the Chiba industrial park.

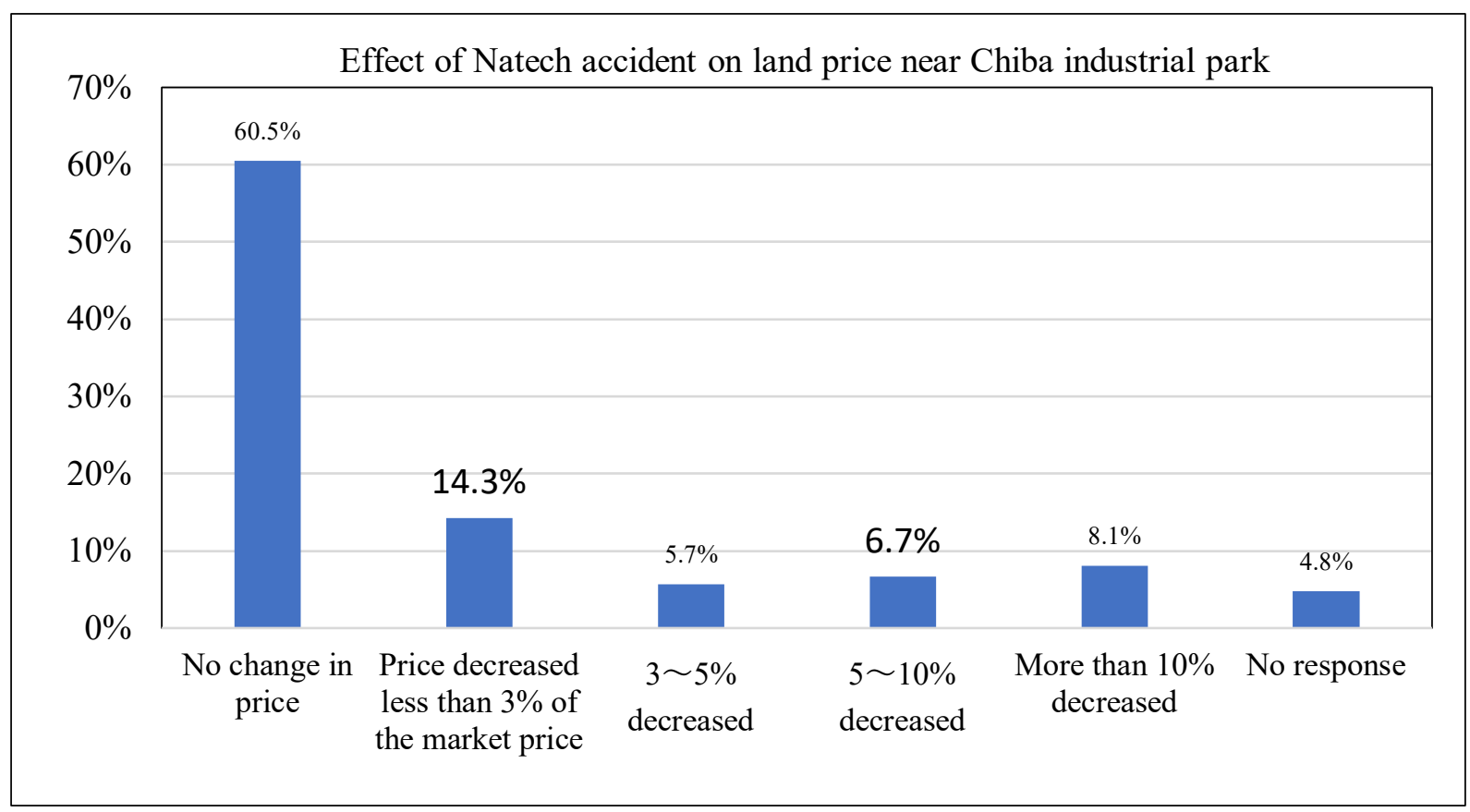

Figure 2. Participant's opinions concerning the effect of the Natech accident on land price 
We asked the survey participants to give their opinion, based on their experience of the Natech accident of 2011, regarding the decrease in land price due to the chemical explosion triggered by Great East Japan Earthquake (Natech accident) and identify the percentage decrease in the land price. Most of the respondents (60.5\%) thought that the chemical explosion (Natech accident) in 2011 did not decrease the land prices near the industrial park, whereas $34.7 \%$ responded that the explosion did decrease the land price in 2011. Of those who believed land prices had declined due to the explosion, $14.3 \%$ of them believed that the incident had declined land prices less than $3 \%$ of the market price. Whereas $8.1 \%$ believed that explosion had decreased land price by more than $10 \%$ of the market price, as shown in Fig. 2.

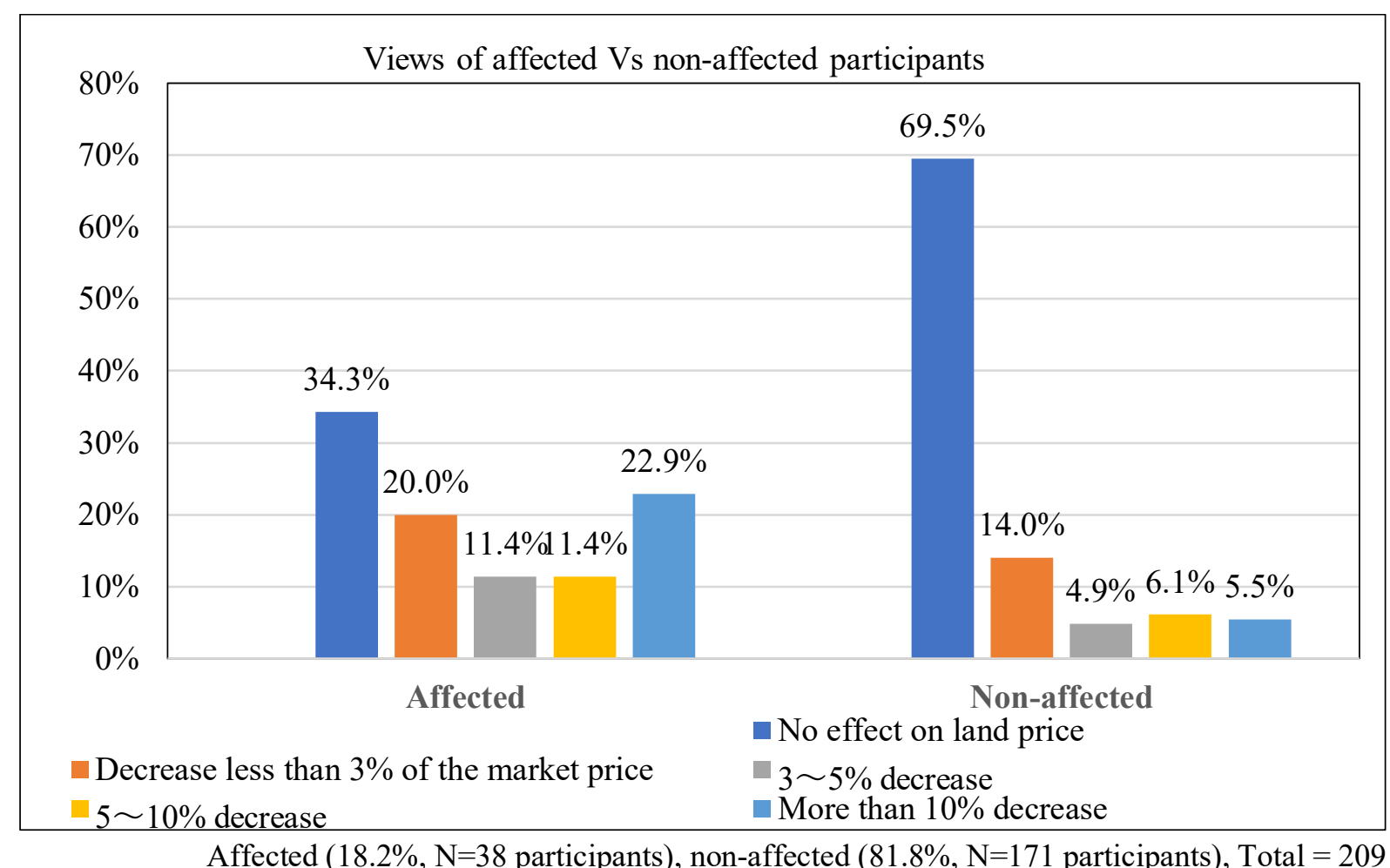

Figure 3. Views of affected and non-affected participants about the impact of the Natech accident on land prices

To better understand the impact of the Natech accident on property prices, survey participants were then divided into the affected and non-affected groups. Those whose houses were damaged by the Natech accident are affected (18.2\%, N=38 participants), whereas those whose houses were not damaged by accident are non-affected $(81.8 \%, \mathrm{~N}=171$ participants). Out of those affected participants (18.2\%) whose houses were damaged by the explosion, most of them responded that the explosion had decreased property values. For example, $20 \%$ thought that the land price had decreased by less than $3 \%$ of the market price, and $11.4 \%$ thought there was a $3 \sim 5 \%$ decrease. Similarly, $11.4 \%$ responded that the land price had decreased $5 \sim 10 \%$, 
whereas $22.9 \%$ of the affected participants thought the land price had decreased by more than $10 \%$ of the market price. While the remaining $34.3 \%$ of the affected participants responded that the event did not negatively impact property values, as shown in Fig. 3. On the other hand, from the non-affected participants $(81.8 \%)$, most non-affected participants $(69.5 \%)$ believed that the accident did not decrease land price. Whereas $14 \%$ of the non-affected participants thought that the land price had decreased less than $3 \%$ of the market price, $4.9 \%$ thought that $3 \sim 5 \%$ decreased, $6.1 \%$ thought $5 \sim 10 \%$ decreased, and 5.5\% believed that more than $10 \%$ of the market price decreased.

We asked the participants if they owned any vacant plots in Ichihara city near the industrial park and if the Natech accident decreased their plot price. From the survey participants, 18.1\% ( $\mathrm{N}=38$ participants) own vacant plots in Ichihara city near the industrial park, whereas the remaining $81.9 \%(\mathrm{~N}=172$ participants) did not own plots at the time of the survey (15 Jan -28 Feb 2020). From the $18.1 \%$ of participants who owned plots, $69.4 \%$ responded that the Natech accident did not decrease the land price, whereas $16.7 \%$ thought that the land price had decreased less than $3 \%$ of the market price, and 5.6\% thought that the land price decrease more than $10 \%$ of the market price. While on the other hand, from the $81.9 \%$ of respondents who did not own vacant plots, $62.2 \%$ reported that the Natech accident did not decrease land price, whereas $14.6 \%$ believed that land price decreased less than $3 \%$, and $9.1 \%$ believed that it decreased more than $10 \%$ of the market price as shown in figure 4 .

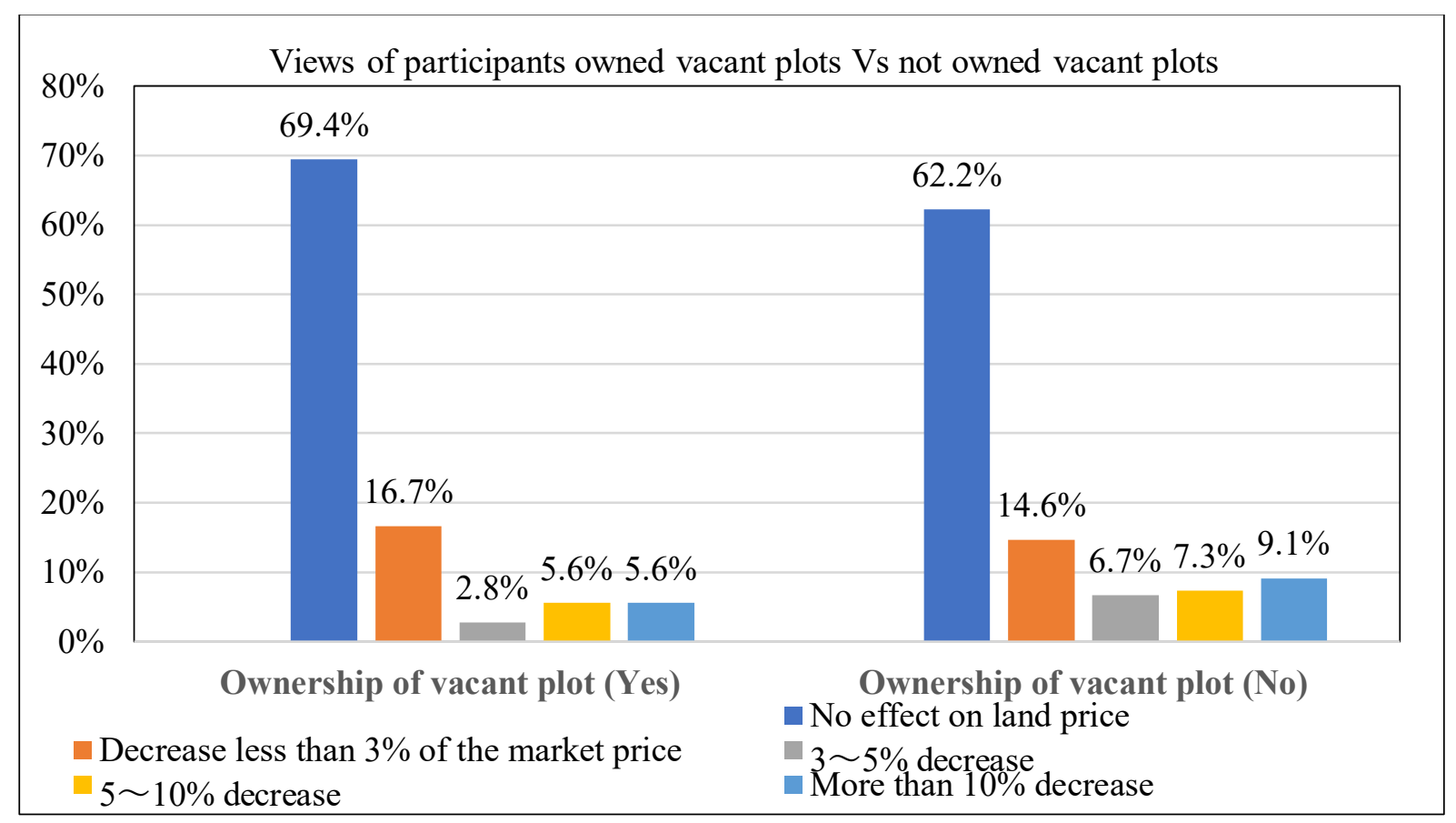

Plots ownership ( $\mathrm{Yes}=18.1 \% \mathrm{~N}=38$ participants, $\mathrm{No}=81.9 \% \mathrm{~N}=172$ participants), Total $=210$

Figure 4. Views of plot owners and non-owners about the impact of the Natech accident on land prices 


\subsection{Households' Perceptions Regarding Chemical and Natech Accident Risk}

This section will explain survey participants' perceptions, experiences, concerns, and worries about the chemical and Natech accident and potential chemical and Natech accident risk. It will also explain their perception about industrial park proximity, their demand for chemical risk information disclosure and their perception regarding the effect of disclosure on future property values. Participants were asked to rate the statements regarding their perceptions using a standard five-point Likert-type scale ranging from 1 = "Strongly Disagree" to 5 = "Strongly Agree." We chose the 5-point Likert scale because it has higher reliability than the 4-point Likert scale (Croasmun and Ostrom, 2011). Moreover, even-numbered Likert scales require the responder to commit to a given position if the Likert scale has no neutral point (Brown 2000), even if the responder may not have a clear opinion. On the other hand, responders are not obligated to choose one side or the other on an issue if they are given a neutral response option; this may minimize the chances of response bias, which is the tendency to favor one response over others (Randall and Fernandes 1991). Some researchers such as Chisty and Rahman (2020), Adeola and Picou (2017), and Krausmann and Baranzini (2012) have used a 5-point Likert scale to investigate people's perceptions and attitudes.

The main aim of this section is to present the results concerning residents' worries and concerns (see fig 5), residents' perceptions about living in the proximity of an industrial park (see fig 6), their demand for chemical risk information, and their perceptions regarding how the disclosure of chemical and Natech risk information affects property values. Through these questions, this study tried to understand households' experiences, concerns, and worries about chemical and Natech accident hazards, their appetite for risk information disclosure concerning these hazards, and their effect on future property values.

\subsection{Households Concerns about Chemical and Natech Accidents}

We asked the survey participants to indicate their concerns and worries about the chemical and Natech accidents at Chiba industrial park and their opinions about the possibility of a future Natech accident at the Chiba industrial park. From the responses that we received, $70.5 \%$ of the survey participants considered the Chiba industrial park explosion a critical problem (mean value=3.79), and they strongly believed that if a large earthquake happens again, there is a high possibility that the Natech accident may occur in the future at the Chiba industrial park (mean value $=4.03$ ). Almost $83.9 \%$ of the survey participants agreed or strongly agreed with the statement that if an earthquake happens, a Natech accident may occur again at the Chiba industrial park. $56.9 \%$ of the survey participants considered chemical and Natech accidents a threat to their life and property (mean value $=3.64$ ), as shown in figure 5 . 

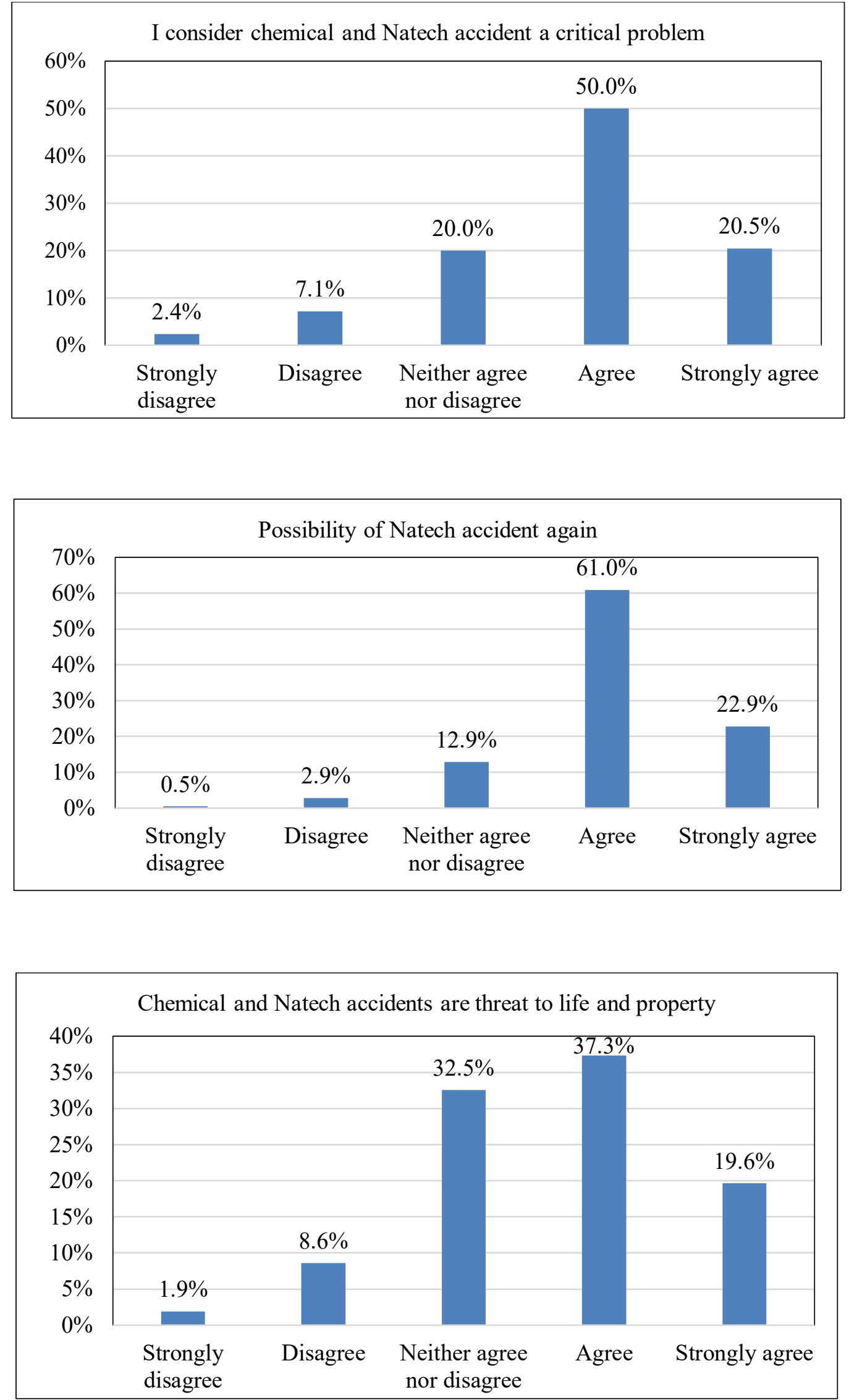

Figure 5. Participants concerns about chemical and Natech accidents where Strongly disagree $=1$, Disagree $=2$, Neither agree nor disagree $=3$, Agree $=4$, and Strongly agree $=5$. 


\subsection{Households' Perceptions Regarding Industrial Park Proximity and Chemical and Natech Accidents Risk}
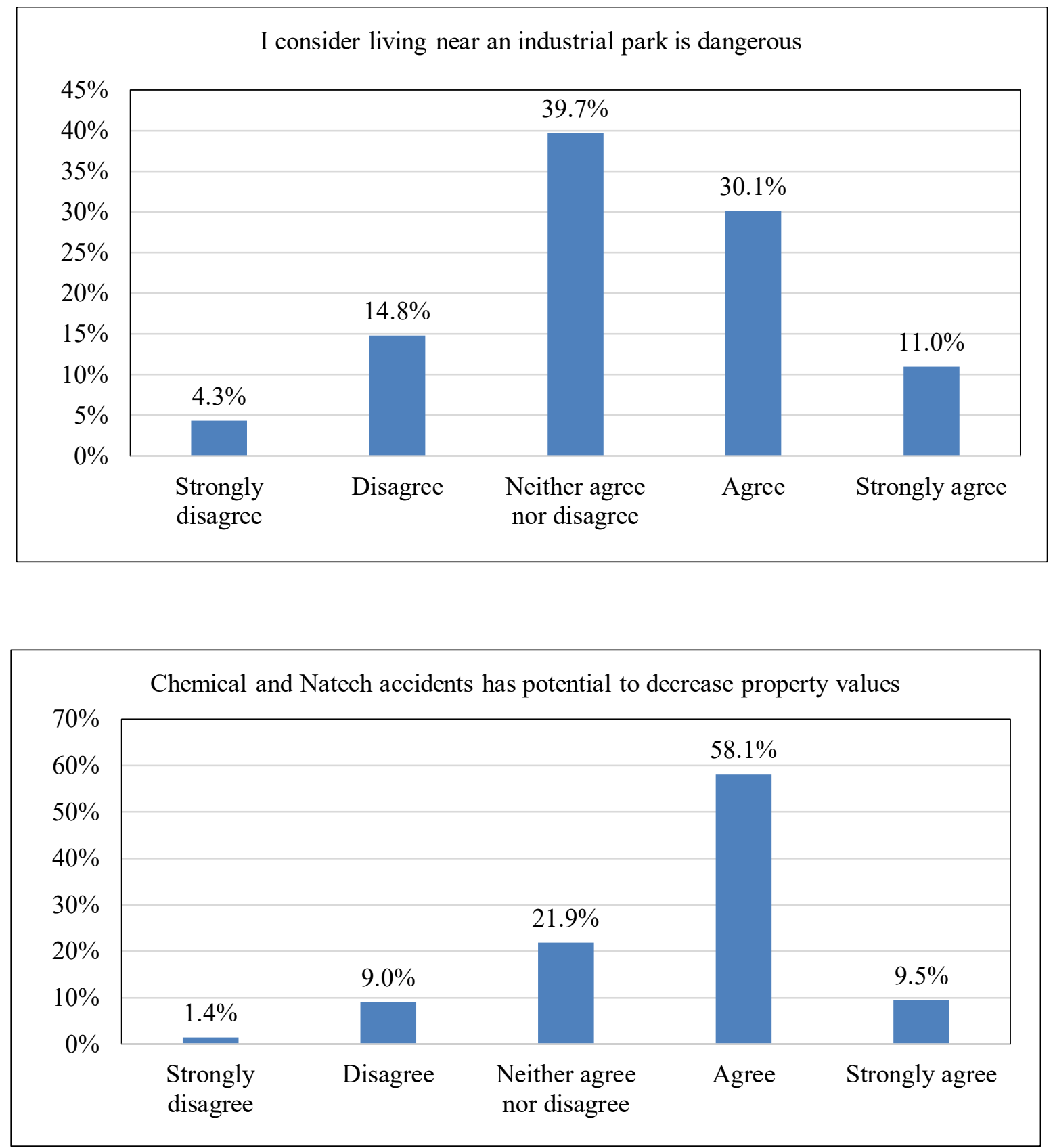

Figure 6. Participants perceptions about industrial park proximity and chemical and Natech accidents risk where Strongly disagree $=1$, Disagree $=2$, Neither agree nor disagree $=3$, Agree $=4$, and Strongly agree $=5$. 
From the survey participants, $41.1 \%$ considered living near the industrial park is dangerous (mean value $=3.29$ ), whereas $39.7 \%$ said they neither agree nor disagree with the statement that living near the industrial park is dangerous, as shown in Fig. 6. Those who consider that living near the industrial park is dangerous, mentioned that they cannot move from their home due to the lack of affordability and emotional attachment to the place. Most of the respondents have been living in the same house for many decades; therefore, it is difficult for them to move to another location. They are concerned that the chemical and Natech accidents has potential to decrease property values in the future near the industrial park (mean value $=3.65$ ). From survey participants, $58.1 \%$ agreed and 9.5\% strongly agreed that chemical and Natech accidents could decrease property values. $21.9 \%$ said they neigher agreed nor disagreed, whereas $10.4 \%$ disagreed or strongly disagreed with the statement that chemical and Natech accidents have the potential to decrease property values in the future, as shown in figure 6 .

\subsection{Households' Perceptions Regarding the Disclosure of Natech and Chemical Risk Information}

The Chiba industrial park's chemical accident in 2011 increased households' awareness of the potential consequences of chemical and Natech accidents, and respondents are now giving priority to chemical risks in their housing decisions (mean value $=3.65$ ). We asked the survey participants if they are giving priority to the chemical and Natech risks in their housing decisions after having an experience of a Natech accident; $62.5 \%$ of the survey participants agreed or strongly agreed that they are giving importance to the chemical and Natech risk in their housing decisions, whereas $26.9 \%$ were neutral with the statement. Regarding chemical risk information disclosure, after experiencing the chemical and Natech accident in 2011, most of the survey participants are now aware of the chemical hazards. They also want to know more about the chemical and Natech risks associated with their places as $44.7 \%$ of the survey participants agreed or strongly agreed (mean value $=3.28$ ) with the statement that they want to know more about chemical and Natech risks associated with their places, while $33.8 \%$ of respondents said they neigher agreed nor disagreed, 16.2\% disagreed and 5.2\% strongly disagreed. On the one hand, many survey participants want to know more about the chemical and Natech risks associated with their places, while on the other hand, they agreed that if the government discloses chemical risk information publicly, then the property values will decrease in their areas (mean value $=3.63$ ). $59.6 \%$ of the survey participants thought that the disclosure would decrease property values, $34.6 \%$ neither agreed nor disagreed, and 5.8\% disagreed with the statement that disclosure will decrease property values, as shown in figure 7. 

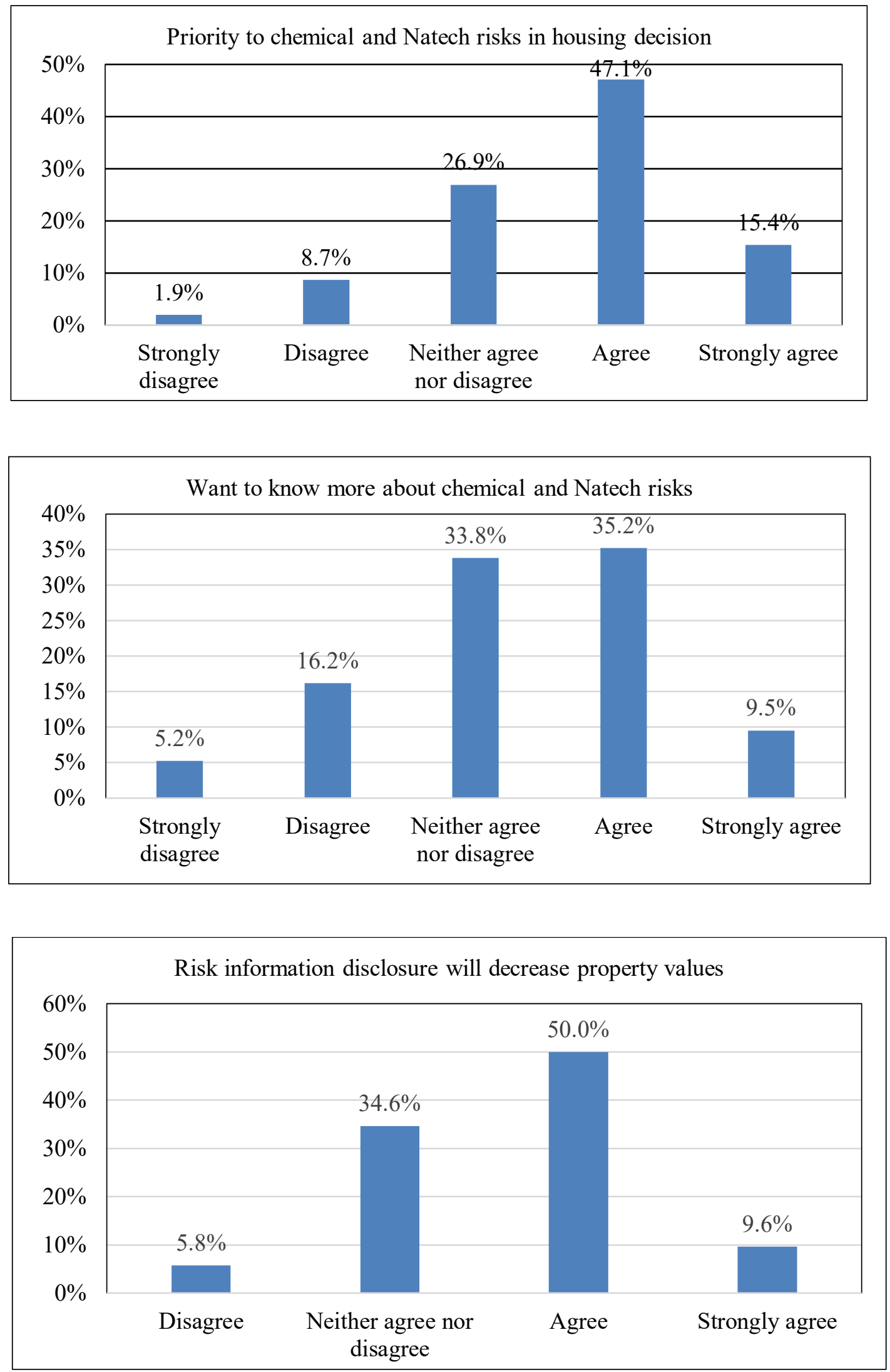

Figure 7. Participants' perceptions about chemical and Natech risk information demand and disclosure where Strongly disagree $=1$, Disagree $=2$, Neither agree nor disagree $=3$, Agree $=4$, and Strongly agree $=5$. 


\section{DISCUSSION AND LIMITATIONS}

This study analyzed households' perceptions of the effect of Natech accidents (actual event) on residential property values and their perceptions regarding the effect of Natech and chemical risk information disclosure on residential property values. The study also investigated households' perceptions, concerns, and worries about the chemical and Natech accident risk and their demand for Natech and chemical risk information disclosure. The research aim was to understand the effect of the Natech accident at Ichihara city on households' perceptions regarding property values, and their perceptions regarding the disclosure of information about potential future chemical and Natech accidents on future property values. The ultimate goal of this research was to better understand households' perceived barriers concerning chemical and Natech risk information disclosure which could help government authorities in developing communication strategies for improved disaster preparedness.

Based on the participants' opinions collected during the household survey, most survey participants whose houses were directly affected by the Natech accident (called affected participants) perceived that the Natech accident decreased the property values. In contrast, those whose houses were not affected (called non-affected participants) by the Natech accident believed that the accident did not decrease the property values. The number of affected participants is smaller $(18.2 \%)$ than the non-affected participants $(81.8 \%)$. Besides, both the affected and non-affected participants were living within $3-\mathrm{km}$ of the industrial park.

Similarly, most survey participants who own vacant plots in Ichihara city believed that the Natech accident did not decrease the land price in 2011. Most participants think property values did not decrease due to the Natech accident because most households only consider and prioritize natural hazards such as earthquakes, floods, and tsunami compared to Natech and chemical risk. In this sense, one participant added a comment: "People forget the chemical accident. Rather than that, I think flood or tsunami risk affects land prices much more, compared to chemical risk. The influence of smoke pollution from industries is more important than chemical accidents." Another respondant said, "As chemical industries are far away from residential areas, the property prices are not influenced by the chemical accident risks." While past studies have found that the properties located in high environmental hazard prone areas subject to earthquakes, tsunami, and floods, have less market value than the properties located in less hazard-prone areas (Bin et al. 2008; Bin and Polasky 2004; Eves and Wilkinson 2014; Hidano et al. 2015; Zhai G et al. 2003), it is not clear that environmental hazards would dominate when compared to chemical and Natech hazard risks.

Although the participants perceived that the Natech accident in 2011 did not decrease the property values, their perception and awareness of chemical and Natech risks has increased since the accident. Most of the surveyed households considered chemical and Natech accidents to be a threat to their lives and properties. They are concerned that chemical and Natech accidents may happen again at the industrial park, and the chemical and Natech accidents have the potential to decline property values in the future. Although participants consider chemical 
and Natech accidents a threat to their lives and properties, and consider that living near an industrial park is dangerous, they cannot move from this place for certain reasons. For example, some respondents noted that they could not afford to buy a house somewhere else away from the industrial park where there is no risk of chemical accidents; others expressed that they have sentiments and emotional feelings attached to their current housing location as their ancestors were living there and they are also living in this place for many years. Therefore, it is difficult for them to move from this place.

Most of the surveyed households are now aware of the chemical and Natech risks. They want to know more about the chemical risks associated with their current housing location. However, they are also concerned that if the government discloses the chemical risk information publicly, it will decrease the property values in the areas closer to the industrial park.

The disclosure of chemical risk is seen as a citizen's right in many wealthy countries (see, for example, the Emergency Planning and Community Right-to-Know Act (EPCRA) in the United States; and the Seveso III Directive in the European Union) and in fact considered unethical not to inform residents about risks they are being subjected to involuntarily (EPCRA 2012; European Union 2012). However, the disclosure of chemical and Natech risk information also requires the dissemination of information regarding disaster prevention and preparedness actions that residents can take to reduce potential consequences, and clear plans on how these hazards and their risks are being addressed. This would help to avoid confilicts. In some countries, the disclosure of natural hazard risk information and communication has led to opposition from individuals who perceive that such disclosure may decline the real estate market. For instance, Montz (1993) found that the publication of hazard maps in New Zealand was encouraged by researchers and censured by the real estate agencies because they perceived that the information would decrease property values.

Therefore, in collaboration with the Chiba industrial park's safety managers, the government should educate the residents by organizing seminars, providing them information about the initiatives that have already been taken to avoid chemical and Natech accidents, and enhancing residents' safety. They should strengthen residents' preparedness training for countermeasures against chemical and Natech accidents and then communicate the chemical hazards information along with positive actions that help to rebuild their trust. However, there is no clear formula on what is the best way to communicate chemical risk information to residents. Therefore, further research is needed to find ways to communicate chemical risk information to the residents that do not make them worried but enhance their preparedness level.

It is important to note that this study has some limitations. For instance, the study only investigated households' perceptions, whereas it did not investigate the perceptions of the real estate agents, government officials in Japan, nor safety managers of industrial facilities, which are imperative in formulating effective policy recommendations for chemical risk information disclosure and developing communication strategies for improved disaster preparedness. Also, the study's overall sample size is small as the survey was voluntary, and no incentives were 
given to the participants. Besides, the survey only covered a limited area in Ichihara city, so the study results cannot be generalized to the whole of Ichihara city and the whole population.

\section{CONCLUSIONS AND FUTURE WORK}

This study has been conducted to understand if the disasters, especially chemical and Natech accidents, negatively impact property values. The study's main purpose was to promote risk information disclosure and develop communication strategies for improved disaster preparedness to protect residents, but the assumption and fear that disclosure will affect property values may bind the government from disclosing chemical risk information. Hence to understand the effect of the Natech accident and chemical risk information disclosure on household's perception regarding residential property values this study has been conducted. The survey collected data from the households living within $3 \mathrm{~km}$ from the Chiba industrial park where a Natech accident happened in 2011 following Great East Japan earthquake and tsunami.

The ultimate goal of this research was to better understand households' perceived barriers concerning chemical and Natech risk information disclosure which could help government authorities in developing communication strategies for improved disaster preparedness. While households perceptions were mixed regarding the impact of the Natech accident during the Great East Japan earthquake on property values, depending on whether they had been directly impacted or not, most residents thought that the disclosure of risk information regarding future events could negatively affect property values. Nonetheless, households indicated that they want to be informed, and that chemical and Natech risk information is one of the most important considerations when thinking about future location choices.

The survey results indicated that the Natech and chemical accidents increased the survey participants' perceptions regarding chemical and Natech risk. Most of the participants are now aware of the chemical and Natech risks, and they are worried about the potential consequences of a chemical and Natech accidents. They want the government to disclose chemical risk information, but they seem to be worried that disclosure may affect their area's property values if the information is made publicly available.

Moreover, residents consider the need to have access to chemical risk information. The study highlights the residents' worries and concerns about potential chemical and Natech accident risks and residents' want to have access to chemical risk information. The survey results highlight the need to take chemical risk communication seriously, while a strategy is needed to mitigate against any property value losses. The study results can have implications on Natech risk governance at the community and industry level.

This study can be improved in several aspects for further research, both methodologically and regarding the analysis scope. For example, it would be instructive to analyze the effect of 
chemical and Natech accidents on property values and residents' perceptions regarding chemical and Natech accidents' effect on the property in other areas where chemical and Natech accidents had occurred in recent years. Since the Natech accident in Ichihara city had occurred several years ago, the effects of the accident may diminish, and residents may forget. Therefore, the analysis of recent chemical and Natech accident on property values and residents' perception of the chemical and Natech accident on property value would help us to better understand whether residents' perceptions about the chemical and Natech accident's effects on property values and the recent chemical and Natech accidents in different regions have similar effects on property values or not. The results can also be further improved by conducting interviews with real estate agents in Ichihara city, which would help get an in-depth understanding of the impact of Natech accidents and chemical risk information disclosure on property values.

Furthermore, the industrial park's safety managers' interviews could also be effective in better understanding the industrial park's initiatives to avoid chemical and Natech accidents, protect citizens, rebuild residents' trust, and ensure a sense of safety and well-being. The interviews from both real estate agents and safety managers would be conducive to developing the policies and programs related to risk communication and disclosure at the local level.

Future research could examine the impact of risk information disclosure on property values in areas where information has already been disclosed. The actual event's experience might have different impacts on people's perceptions and perceptions concerning property values. Hence further research is needed to fill the gaps and make policy recommendations for developing communication strategies for improved disaster preparedness and risk communication in Japan.

\section{REFERENCES}

Adeola, F.O., and Picou, J.S. (2017) Hurricane Katrina-linked environmental injustice: race, class, and place differentials in attitudes. Disasters, 41 (2): 228-257. https://doi.org/10.1111/disa.12204

Beron, K. J., Murdoch, J. C., Thayer, M. A., and Vijverberg, W. P. M. (1997) An analysis of the housing market before and after the 1989 Loma Prieta earthquake. Land Economics, 73(1): 101-113. https://doi.org/10.2307/3147080

Bin, O., Kruse, J. B., and Landry, C. E. (2008) Flood hazards, insurance rates, and amenities: Evidence from the coastal housing market. The Journal of Risk and Insurance, 75 (1): 6382. https://www.jstor.org/stable/25145263

Bin, O., and Polasky, S. (2004) Effects of Flood Hazards on Property Values: Evidence Before and After Hurricane Floyd, 80 (4): 490-500. https://doi.org/10.2307/3655805

Boxall, P. C., Chan, W. H., and McMillan, M. L. (2005) The impact of oil and natural gas facilities on rural residential property values: A spatial hedonic analysis. Resource and Energy Economics, 27 (3): 248-269. https:/doi.org/10.1016/j.reseneeco.2004.11.003 
Brown, J.D. (2000). What issues affect Likert-scale questionnaire formats? JALT Testing \& Evaluation SIG, 4 (1), 27-30. https://hosted.jalt.org/test/PDF/Brown7.pdf

Croasmun, J. T., \& Ostrom, L. (2011). Using Likert-type Scales in the Social Sciences. Journal of Adult Education, 40 (1): 19-22. https://files.eric.ed.gov/fulltext/EJ961998.pdf

Chisty, M.A., and Rahman, M.M., 2020. Coping capacity assessment of urban fire disaster: An exploratory study on ward no: 30 of Old Dhaka area. International Journal of Disaster Risk Reduction, 51. https://doi.org/10.1016/j.ijdrr.2020.101878 EPCRA. (2012) The Emergency Planning and Community Right-to-Know Act. https://www.epa.gov/epcra/what-epcra

European Union. (2012) Directive 2012/18/EU of the European Parliament and of the Council of 4 July 2012 on the control of major accident hazards involving dangerous substances, amending and subsequently repealing Council Directive 96/82/EC. Off. J. Eur. Union. 197, 1.

Eves, C., and Wilkinson, S. (2014) Assessing the immediate and short-term impact of flooding on residential property participant behavior. Natural Hazards, 71 (3): 1519-1536. https://doi.org/10.1007/s11069-013-0961-y

Elisabeth Krausmann and Daniele Baranzini (2012) Natech risk reduction in the European Union, Journal of Risk Research, $15 \quad$ (8): 1027-1047. https://doi.org/10.1080/13669877.2012.666761

Randall, D., and Fernandes, M. (1991). The social desirability response bias in ethics research. Journal of Business Ethics, 10 (11): 805-817. https://doi.org/10.1007/BF00383696

Gentle, N., Kierce, S., and Nitz, A. (2001) Economic Costs of Natural Disasters in Australia. The Australian Journal of Emergency Management, $16 \quad$ (2): 38-43. https://search.informit.org/doi/10.3316/informit.378155558898334

Grislain-Letrémy, C., and Katossky, A. (2014) The impact of hazardous industrial facilities on housing prices: A comparison of parametric and semiparametric hedonic price models. Regional Science and Urban Economic, 49, 93-107. https://doi.org/10.1016/j.regsciurbe co.2014.09.002

Hidano, N., Hoshino, T., and Sugiura, A. (2015) The effect of seismic hazard risk information on property prices: Evidence from a spatial regression discontinuity design. Regional Science Und Urban Economics, 53, 113-122. https://doi.org/10.1016/j.regsciurbeco.2015.05.005

Ikeda, Y. (2013) The Construction of Risk and the Resilience of Fukushima in the Aftermath of the Nuclear Power Plant Accident, in Steger, B., Gill, T., and Slater, D. H. (Eds.), Japan Copes with Calamity: Ethnographies of the Earthquake, Tsunami and Nuclear Disasters of March 2011. Bern; New York: Peter Lang Publishing, 151-175.

Kinoshita, T. (2014) Short History of Risk Communication in Japan. Journal of Disaster Research, 9, 592-597. https://doi.org/10.20965/jdr.2014.p0592

Koseki, H., Li, X., and Mannan, M. S. (2012) Damage to chemical and oil complexes following the 2011 Tohoku earthquakes. Loss Prevention Bulletin, (226): 12-15.

Kotani, Hitomu, and Muneta Yokomatsu. 2019. 'Quantitative Evaluation of the Roles of Community Events and Artifacts for Social Network Formation: A Multilayer Network Model of a Community of Practice'. Computational and Mathematical Organization Theory 25 (4): 428-63. https://doi.org/10.1007/s10588-018-9277-5. 
Krausmann, E., and Cruz, A. M. (2013) Impact of the 11 March 2011, Great East Japan earthquake and tsunami on the chemical industry. Natural Hazards, 67 (2): 811-828. https://doi.org/10.1007/s11069-013-0607-0

Kivimäki, M., and Kalimo, R. (1993) Risk Perception Among Nuclear Power Plant Personnel: A Survey. Risk Analysis 13 (4): 421-424. https://doi.org/10.1111/j.15396924.1993.tb00742.x

Lambley, D., and Cordery, I. (1997) The Effects of Catastrophic Flooding at Nyngan and Some Implications for Emergency Management. The Australian Journal of Emergency Management, 12(2):

$5-9$. https://search.informit.org/doi/10.3316/ielapa.400962315718371

Lamond, J. E. (2008) The impact of flooding on the value of residential property in the UK. In Dept. of the build environment and engineering. https://wlv.openrepository.com/bitstream/handle/2436/31427/Lamond_PhDthesis.pdf?se quence $=1 \&$ isAllowed $=\mathrm{y}$

Montz, B. E. (1993) Hazard area disclosure in New Zealand: the impacts on residential property values in two communities. Applied Geography, 13 (3): 225-242. https://doi.org/10.1016/0143-6228(93)90002-I

Naoi, M., Seko, M., and Sumita, K. (2009) Earthquake risk and housing prices in Japan: Evidence before and after massive earthquakes. Regional Science and Urban Economics, 39(6): 658-669. https://doi.org/10.1016/j.regsciurbeco.2009.08.002

Rajapaksa, D., Wilson, C., Managi, S., Hoang, V., and Lee, B. (2016). Flood Risk Information, Actual Floods, and Property Values: A Quasi-Experimental Analysis. Economic Record, 92 (S1): 52-67. https://doi.org/10.1111/1475-4932.12257

Rambaldi, A. N., Fletcher, C. S., Collins, K., and McAllister, R. R. J. (2013) Housing Shadow Prices in an Inundation-prone Suburb. Urban Studies, 50 (9): 1889-1905. https://doi.org/10.1177/0042098012465904

Statistics Bureau Japan (2015). City Population, Ichihara. Accessed from https://www.citypopulation.de/en/japan/chiba/_/12219__ichihara/

Samarasinghe, O., and Sharp, B. (2010) Flood prone risk and amenity values: A spatial hedonic analysis. Australian Journal of Agricultural and Resource Economics, 54 (4): 457-475. https://doi.org/10.1111/j.1467-8489.2009.00483.x

Tanaka, K., and Managi, S. (2016) Impact of a disaster on land price: evidence from Fukushima nuclear power plant accident. In Singapore Economic Review, 61 (1). World Scientific Publishing Co. Pte Ltd. https://doi.org/10.1142/S0217590816400038

Troy, A., and Romm, J. (2004) Assessing the price effects of flood hazard disclosure under the California Natural Hazard Disclosure Law (AB 1195). Journal of Environmental Planning and Management, 47 (1). https://doi.org/10.1080/0964056042000189844

Yeo, S. (2004) Are residential property values adversely affected by disclosure of flood risk. In Staying Afloat: floodplain management conference of NSW, Coffs Harbour, 267-272. https://www.researchgate.net/publication/312779703_Are_residential_property_values_a dversely_affected_by_disclosure_of_flood_risk

Yeo, Stephen. (2003) Effects of disclosure of flood-liability on residential property values. Australian Journal of Emergency Management, 18 (1): 35-44. https://search.informit.org/doi/abs/10.3316/ielapa.377037580622842 
Zhai G, Fukuzono T, and Ikeda S. (2003) Effect of Flooding on Megalopolitan Land Prices: A Case Study of the 2000 Tokai Flood in Japan. Journal of Natural Disaster Science, 25 (1): 23-36. https://jsnds.org/jnds/25_1_4.pdf

Zhang, Y., Hwang, S. N., and Lindell, M. K. (2010) Hazard Proximity or Risk Perception? Evaluating the Effects of Natural and Technological Hazards on Housing Values. Environment and Behavior, 42 (5), 597-624. https://doi.org/10.1177/0013916509334564 